ROCZNIK ADMINISTRACJI PUBLICZNEJ 2020 (6)

ARTYKUŁY / ARTICLES

Administracyjne prawo ustrojowe

Administrative systemic law

MAŁGORZATA KMAK ${ }^{1}$

\title{
The Municipal Council in the Polish Local Government Structure: Selected Aspects
}

\section{Introduction}

The changes that took place in Poland after 1989 shaped the contemporary model of the municipality. Municipalities were entrusted with some powers. The position of the municipal council in Poland was established by the Act of 8 March 1990 on local government. The municipality 'gives an insight into local needs and conditions which are not known to higher authorities, ${ }^{2}$ one reads. In practice, this means that the municipality, through the municipal council, is to provide solutions that will satisfy the needs of the local community. The aim of the article is to diagnose organisational solutions concerning the municipal council in Poland. The main premise is the conviction that the process of evaluating the structure and functioning of the municipal council is conditioned by the involvement of the municipality's residents who experience its influence on their daily lives, including the satisfaction of their needs.

The administrative division of the Republic of Poland includes threetiers. The tasks of the state administration have therefore been divided between the provincial, district and municipal government levels. The lowest tier is the municipality, whose position is established by the Constitution of the Republic of Poland of 2 April 1997 and other Acts of law. As the basic unit of territorial division - the municipality organises society in such a way as to satisfy the needs of individuals and the whole community in the most effective and efficient way. Created by the citizens and being at the same time closest to them, it performs its public tasks - also of local significance.

1 Doctor of Humanities, Institute of Political Sciences and Administration, Department of Sustainable Development Research, Pedagogical University of Kracow.

2 Z. Leoński, Samorząd terytorialny w RP, Warsaw 1998, p. 9. 


\section{The concept of local government}

The concept of local government did not appear in the study of administrative law until the 19th century. A community capable of delegating certain administrative functions to its elected representatives is the basis for the functioning of local government. Local government is a type of self-government that encompasses all people who live in the territory of a given basic territorial unit. According to Wiesław Kisiel, local government is a local community which has a democratic internal structure, distinguished by law in order to perform certain tasks in public administration in a decentralised way ${ }^{3}$. The author points out that being a local community, local government is created to support public administration in carrying out its tasks within the limits of applicable law. According to Bogdan Dolnicki, local government, in the legal (corporate) sense, should be 'understood as performing public administration tasks, in a decentralised way and on its own account, by entities separate from the state, which are not subject to any state interference in the performance of their tasks. ${ }^{4}$

\section{An outline of local government history in Poland}

The development of local government in Poland began in the period of the state monarchy - after the adoption of the Constitution of 3 May 1791. At that time, provisions regulating the competences of the municipal government appeared. They granted the royal cities the right to elect their own local governments as well as appoint mayorsand other officials ${ }^{5}$. However, later on, the loss of Poland's independence resulted in significant differences in the development of local government in its former territories. The role and notion of local government in each part of the partitioned country was different and dependent on the legal system in force.

In 1918, after Poland regained independence, the Second Polish Republic was able to merge its territories also in terms of administration. The main role was played by the Constitution of March 1921, which introduced a formal three-stage territorial division of the country into provinces, districts, and urban and rural municipalities. The Constitution assumed that the state system would be based on the principle of self-government, giving local government a certain autonomy in areas such as administration, culture and management ${ }^{6}$. The development of the notion of local government

3 K. Bandarzewski, P. Chmielnicki, W. Kisiel, Prawo samorzadu terytorialnego $w$ Polsce, Warsaw 2006, p. 14.

4 B. Dolnicki, Samorzad terytorialny, Cracow 2006, p. 17.

5 A. Gołębiowska and P. Zientarski, Funkcjonowanie samorządu terytorialnego - uwarunkowania prawne i społeczne, Warsaw 2016, p. 13.

6 H. Zięba-Załucka, Samorząd terytorialny Rzeczypospolitej Polskiej po reformie ustrojowej, Rzeszów 1999, p. 6. 
led to the adoption of the 'Integration Act' in 1933, which entered into force on 23 March that year, titled 'Act on a partial change of the local government system'. It assumed, however, that the competence of the province governor (a state government body) would be increased, thus narrowing the scope of local governments' autonomy. The Constitution of April 1935 introduced further restrictions on the role of local government, reducing its competences to local tasks only.

The periods of the Second World War and the Polish People's Republic effectively inhibited the development of local government and led to its destruction. Not only local government units but also all associations with self-government structures were dissolved. Since 20 July 1983, the territorial system of the Republic of Poland functioned with the help of local national councils but the only thing they had in common with local government was the name. Although the notion of local government was reinstated, national councils did not enjoy any financial or property-related independence. At that time, the territorial division was two-tier and included municipalities as the basic level units and provinces as the second level units.

It was only the political transformation that took place in Poland after 1989 that led to the commencement of work on the reconstruction of local government structures, which only then gained a guaranteed share in the exercise of power. The Round Table Talks, during which also agreement on the issue of self-government was reached, contributed to this. That included: granting legal personality to municipalities, transferring part of state property to them, ensuring permanent electoral law and the possibility for local governments to contest the decisions of state authorities before the Supreme Administrative Court and common courts. This initiated a number of changes in the 1952 Constitution, which, among others, guaranteed local government participation in the exercise of power. Thanks to these modifications of 1990, it was possible to prepare drafts of the Acts on local government, as well as the electoral systems for municipal councils. The electoral law made it possible to prepare and conduct elections to the newly established municipal councils on 27 May 1990. Municipality councils were established on the basis of the Act on municipal government, which introduced local government based on the dualism of both central-and local-government administration. The national councils were dissolved and replaced with self-governing municipalities, which started to perform public functions in their own name and on their own account. The new self-government regulations placed the municipality in the role of heir to those spheres of public affairs which were excluded from the government's authority. The first local government elections also triggered the reconstruction of the state administration and strengthened the new position of local government as an element of the political system ${ }^{7}$.

7 D. Tecław, Ewolucja samorzadu terytorialnego w Polsce w latach 1989-1998, Poznań 2015, p. 129-130. 


\section{The legal basis for the functioning of local government in Poland}

In the Polish legal system, regulations covering local government could appear no sooner than after amending the Constitution ${ }^{8}$. Therefore, it is only since 2 April 1997 that the basic issues related to local government have been regulated. The Constitution of the Republic of Poland together with a package of Acts of law on local government, such as the Act of 8 March 1990 on municipal, district and provincial government, the Act of 24 July 1998 on the introduction of the basic three-tier territorial division of the country and the European Charter of Local Self-Government, has become the basis for defining and regulating the system and tasks of local government.

As the existence of local government is an important feature in democratic countries, the Polish Constitution of 1997 contains much broader regulations concerning local government units than its previous versions ${ }^{9}$. Chapter VII titled 'Local Government is entirely dedicated to regulations concerning it. The legislator has established that local government shall perform public tasks, not reserved by the Constitution or other Acts of law, for bodies of other public authorities ${ }^{10}$. Under the provisions of that chapter, each local government unit has legal personality, right to property and other rights. The legislator also stipulates that the independence of local government units is subject to judicial protection. The Constitution also refers to the issue of creating local government units, but it only establishes the need for a municipality to exist as the basic unit of the local government system. Local governments' revenues are: own revenues, general subsidies and special purpose subsidies from the state budget. The Constitution of the Republic of Poland also guarantees local government units a share in public income according to the tasks assigned to them. It leaves at their disposal the right to determine the amount of local taxes and fees, however not exceeding the scope defined in accordance with the law. Therefore, local government units carry out their tasks through their legislative and executive authorities, financed by the state budget but also using their own revenues. Additionally, each local government authority may be dissolved by the Sejm at the request of the Prime Minister, however only in cases where the authority grossly violates the Constitution or Acts of law. The legislator has also defined the manner of exercising supervision over the activities of local government. This is to be based primarily on the criterion

8 A. Gołębiowska, P. Zientarski, E. Stępień, Konstytucja Rzeczypospolitej Polskiej a samorzad terytorialny, in: Funkcjonowanie samorzadu terytorialnego - uwarunkowania prawne i społeczne, A. Gołębiowska, P. Zientarski (eds.), Warsaw 2016, p. 15.

9 A. Gołębiowska, P. Zientarski, E. Stępień, Konstytucja..., p. 15-16.

10 A. Gołębiowska, Istota samorządu terytorialnego w świetle postanowień Konstytucji Rzeczypospolitej Polskiej z dnia 2 kwietnia 1997 r., Warsaw 2015, p. 18-27. 
of legality, i.e. compliance with the law. The following supervisory authorities have been established: the Prime Minister and province governors, and, in the area of finance, regional chambers of audit. Detailed regulations relating to the manner of exercising supervision over local government are contained, among others, in the 'systemic Acts of law', i.e. in the Act on municipal government, the Act on district government and the Act on provincial government ${ }^{11}$. The Polish Constitution also provides for the possibility to hold a local referendum. Therefore, the citizens may decide on matters concerning their local community. This decision may concern e.g. dismissal of a local government body that has been elected in direct elections ${ }^{12}$. The Polish Constitution also grants local government units the right of association. This right applies both to national self-government units and international associations of local and regional communities as well as to cooperation with regional and local communities in other countries $^{13}$. Therefore, the legislator has left the possibility of extensive cooperation between local government units. It may be of a local or regional nature, and the cooperating entities may be from neighbouring European countries or even ones from other continents ${ }^{14}$. The provisions relating to the existence and operation of local government appear also outside Chapter VII of the Polish Constitution. In Article 16, the legislator guarantees that the residents of units of the basic territorial division constitute self-governing communities by law, while local government has the right to participate in the exercise of public authority. This is expressed in the performance of public tasks it is entitled to within the framework of the Acts of law, which the local government performs in its own name and on its own account ${ }^{15}$.

The European Charter of Local Self-Government marked the path leading to a pan-European unification of views on local government. It was signed in Strasbourg on 27 June 1985 by members of the Council of Europe. Its aim was to harmonise the law on local government and its units in Europe. The Charter was also intended to ensure that the Council's members would cooperate in resolving local problems democratically, taking into account the principle of respect for their heritage ${ }^{16}$. In this way, the Charter has contributed to the development of the position of local authorities in the system of countries that ratified it. Even before the ratification

11 Z. Dolewka, System kontroli i nadzoru w samorzadzie terytorialnym, Wrocław 2013, p. 31.

12 A. Gołębiowska, P. Zientarski, E. Stępień, Konstytucja..., p. 17.

13 A. Gołębiowska, Local government in the Constitution of Republic of Poland of 1997, Warsaw 2015, p. 38-41.

14 R. Kusiak-Winter, Wspótpraca ze społecznościami lokalnymi i regionalnymi innych państw jako zadanie jednostek samorzadu terytorialnego $w$ Polsce, University of Wrocław, p. 420.

15 A. Gołębiowska, Istota samorządu..., p. 25-27.

16 Z. Leoński, Zarys prawa administracyjnego, Warsaw 2004, p. 143. 
of the Charter, the Polish legal system had already seen the introduction of provisions implementing the values it represented. Poland ratified the European Charter of Local Self-Government on 22 November 1993. In its first articles, the Charter defines local government as the right and ability of local communities to manage and administer the fundamental part of public affairs within legally defined boundaries, on their own account and in the interest of their residents ${ }^{17}$. This definition is compatible with the definition of local government in Article 16 of the 1997 Polish Constitution. Like the Polish basic law, the Charter bases the operation of local government units on the principle of subsidiarity, recognising that this principle is implemented by a transfer of certain public tasks to the authorities closest to the citizens. The Constitution recognises municipality authorities as these authorities. According to Article 8 of the Charter, the control of these authorities is supposed to examine their compliance with the law, which is reflected in Article 171 of the Polish Constitution. In all other respects, such as the principles of financing the activities of local authorities, both legal acts also remain analogous. This is also the case when it comes to the right of local communities to associate and cooperate with other local communities expressed in Article 10 of the Charter. The European Charter of Local Self-Government grants judicial protection to local government units in order to protect their self-government, as does Article 165(2) of the Polish Constitution. Both legal acts also indicate the role of the municipality as the basic unit of local government. The European Charter of Local Self-Government also contains provisions regulating the authority of local governments. It states that the local government issues regulated in the Constitution and national legislation make it one of the fundamental legal and administrative institutions of the state ${ }^{18}$.

According to Article 164 of the Polish Constitution, the municipality is the basic unit of territorial division, with the proviso that other units of local government are determined by Acts of law. This provision led, in June 1998, to the adoption by the Sejm of the Act on district government and the Act on provincial government, resulting in the replacement of the two-tier territorial division existing since 1975, by a three-tier division in force since 1 January1999. Apart from the municipality established under the Constitution of 7 April 1997, the districts and provinces were also to be units of state territorial division. The newly created administrative map included 16 new provinces and 373 new districts ${ }^{19}$. Although the number of provinces has remained unchanged so far, the number of districts and municipali-

17 Journal of Laws 1994 No. 124 item 607.

18 B. Dolnicki, Ustawa o samorządzie gminnym komentarz, Warsaw 2016, p. 17.

19 R. Brol, Kryteriadelimitacjipowiatów, w: Gospodarka lokalna i regionalna $w$ teori i ipraktyce, R. Brol (ed.), Wrocław 2004, p. 333. 
ties is still subject to minor changes and slight adjustments of the boundaries between the units occur almost every year.

The largest of the units of the basic territorial division (i.e. the province) has been defined as a territory and all its residents forming a regional self-government community by law. The change in the number of provinces from 49 to 16 was aimed at creating large and strong units for which it would be easier to undertake regional international or cross-border cooperation and use more effectively EU legal and financial instruments for regional development. Larger provinces can also contribute to greater decentralisation by taking over a larger part of public authority ${ }^{20}$. The newly created provinces have therefore become both government and self-government units. This is due to the fact that the administrative power in these units is exercised by the provincial assembly, which is the core of local government elected by universal suffrage, and the executive authority in the form of the marshal's office, with the province marshal elected by the assembly. The governmental authority is represented by the provincial office headed by the province governor, appointed by the Prime Minister to supervise the legality of the activities of the provincial government. Under the Act of 5 June 1998 on provincial government, the provinces do not have any authority over districts and municipalities despite the fact that they became the largest territorial division units. They are not supervisory, control or higher authorities in administrative proceedings, either. Also, the activities of the provincial government must not violate the independence of districts and municipalities.

The district as a territorial division unit was restored after 23 years and took an intermediate place in the three-tier division, between the province and the municipality. Its residents became a local government community by law. It was established under the Regulation of the Council of Ministers of 7 August 1998, which defined its boundaries by listing municipalities forming a district ${ }^{21}$. Additionally, some of the larger cities were granted the status of cities with district rights. In terms of population, Warsaw is the largest of such cities ${ }^{22}$. The district is headed by the district council and the district board. The council is the legislative and controlling authority and its members are chosen in direct elections. The board is the executive body of the district. The function of the chairman of the board is performed by the district governor, who sits on the board together with the deputy district governor and other members. Members of the district board are elected by the district council. The district car-

20 P. Chmielnicki, Komentarz do ustawy o samorzadzie województwa, Warsaw 2005, p. 14.

21 B. Suchodolski, Zarys historii administracji samorządowej w Polsce, Siedlce 2013, p. 8.

22 GUS, Bank danych lokalnych, Gminy największe pod względem powierzch$n i-$ as at 31 December 2019. 
ries out public tasks assigned to it on the basis of the act and they are not restricted to municipalities. These include e.g. maintenance of secondary schools, hospitals or district roads.

The municipality is the smallest unit of territorial division. The legislator has described it as a specific territory with its residents who, by law, form a local government community. Depending on the area they cover, three types of municipalities have been established. Rural municipalities include rural areas, rural-urban municipalities include rural areas together with the area of the city located in this rural area. Urban municipalities cover only the city area. The municipal council elected by universal suffrage is a legislative and controlling body of the municipality. The executive authority is made up of mayors: in rural municipalities - the village mayor (wójt), in urban and rural-urban municipalities - the town or city mayor (burmistrz and prezydent, respectively).

\section{The municipality as the basic unit of local government}

The municipality is a territorial division unit, but also an independent entity with legal personality. It operates under the supervision of the state authority yet to some extent maintains its independence, which is subject to judicial protection. Municipalities are merged, divided or created and dissolved by means of a regulation issued by the Council of Ministers after consultation with the residents who, by law, form a local government community. Local government is therefore a fundamental form of organisation of public life in the municipality. Being a local government community, the municipality performs public tasks of two categories: its own tasks (obligatory and optional) and commissioned tasks (by law and agreement). Its obligatory own tasks must be carried out by the municipality itself - they are mandatory, whereas optional tasks are not indispensable. They are performed if after completing the obligatory tasks, the municipality still has sufficient financial resources ${ }^{23}$. According to Article 7 of the Act of 8 March 1990 on municipal government, the own tasks include meeting the collective needs of the community related to:

1) technical infrastructure:

- municipal roads, bridges, squares and traffic organisation,

- telecommunication-related activities,

- supply of electricity and heat, gas, water, sewage system, removal and treatment of municipal sewage, maintenance of cleanliness and order as well as sanitary facilities, landfills and disposal of municipal waste;

23 A. Harańczyk, Samorzad terytorialny - organizacja i gospodarka, Cracow 2010 , p. 26. 
2) social infrastructure:

- popularisation and support of the notion of local government, including creation of conditions for operation and development of auxiliary units and implementation of programmes increasing civic activity,

- promotion of the municipality,

- cooperation with regional and local communities of other countries,

- pro-family policies, including the provision of social, medical and legal care to pregnant women,

- maintenance of municipal public buildings and facilities and administrative facilities,

- municipal housing,

- public education,

- culture, including municipal libraries and other cultural institutions, as well as monument protection and care,

- physical culture and tourism, including recreational areas and sports facilities,

- market places,

- supporting the family and foster care system,

- social welfare, including care centres,

- health care,

- local public transport;

3) public order and safety:

- public order and safety of citizens as well as fire and flood protection, including equipment and maintenance of a municipal flood protection warehouse;

4) spatial and environmental order:

- spatial order, as well as real estate management, environmental protection and water management,

- municipal cemeteries,

- municipal greenery and trees.

The municipality carries out the tasks on its own behalf and on its own account, according to the principles formulated in the Acts of law. It cannot evade their execution. The transfer of new own tasks to the municipality by statutory means requires the provision of financial resources necessary for their implementation, by increasing its own income or subsidies and grants. The origin of financial resources depends on the type of the task being performed. Pursuant to Art 8 of the Act of 8 March 1990 on municipal government, the municipality may also carry out tasks in the field of government administration on the basis of an agreement with the authorities of this administration. The performance of commissioned tasks by the municipality results in a dual nature of its activity: a local government community and a government administration executive unit. Local government 
receives targeted subsidies from the central government administration to carry out these tasks. When transferring public funds for the performance of commissioned tasks, government administration authorities have the right to control the funds spent, also in terms of the purposefulness and economy of their activities. The municipality may also carry out tasks of a district and a province on the basis of an agreement between these local government units ${ }^{24}$.

\section{Municipality authorities}

The notion of authority in a municipality correlates with the performance of public administration by the municipality or local community ${ }^{25}$. According to Article 11 of the Act of 8 March 1990 on municipal government, the local community, i.e. the residents of the municipality, shall take decisions by universal suffrage (in the form of elections or a referendum) or through the municipality council and the mayor.

The Act recognises the village mayor (town or city mayor) as the executive body of the municipality. This means that he/she performs the tasks resulting from the resolutions of the municipal council and has legal obligations resulting only from the legal regulations provided for his/her function. The mayor is also a supervisory and control authority of the bodies of the municipality's subsidiary units and supervises the activities of the heads of municipal organisational units. The mayor performs all tasks through the municipal office of which he/she is the head. And his/her responsibilities include: execution of the municipal budget adopted by the municipal council, preparation of draft resolutions for the municipal council and determination of the manner of their execution, as well as management of municipal property. The mayor also performs municipality tasks specified by law. This refers to the list of municipality tasks contained in the Act of 8 March 1990 on municipal government as well as in the provisions of other Acts of law. The (village, town or city) mayor is elected in direct, general and secret elections, and his/her term of office starts on the day of the beginning of the term of the municipal council and also expires on the day of the expiry of its term of office. The mayor is also forbidden to combine his/her function with the function of a mayor or deputy mayor in another municipality ${ }^{26}$.

The municipal council is a legislative and controlling body in the rural municipality. In urban municipalities, it is the city council. These are collective bodies, acting during sessions, through appropriate committees.

24 A. Harańczyk, Samorzą...., p. 28-29.

25 M. Augustyniak, Samorzą terytorialny, in: Prawo administracyjne, M. Zdyb, J. Stelmasiak (eds.), Warsaw 2016, p. 384.

26 Ibidem, p. 392-400. 
Municipal councils (city councils) decide, by means of resolutions, on all local matters within the scope of their activities which have not been reserved for the residents ${ }^{27}$. The term of office of the council lasts five years counting from the election date. It is the same as the term of office of the councillors. The municipal council may not change the term of office of its internal authorities, such as the chairman and the deputy chairmen of the council, committees and teams, or the term of office of auxiliary units. All actions of the municipal council taken after the expiry of its term of office are illegal. After the expiry of the term of office, the work in the municipal council is also discontinued. The internal organisation and manner of operation of the municipal authorities is defined in the municipality statute. It is adopted by the municipal council, which also has the right to amend the statute. It is binding within the area of the municipal authorities and regulates public matters of a local nature ${ }^{28}$.

\section{Tasks and powers of the municipal council}

The tasks and powers of the municipal council are defined in Articles 18 and 18a of the Act of 8 March 1990 on municipal government, as amended. It establishes the assumption of the competence of the municipal council in all matters within the scope of its operation, unless Acts of law provide otherwise, while at the same time indicating the basic role of the council in the system of municipal authorities. On this basis, two functions of the municipal council can be distinguished: the function of a controlling body and the function of a legislative body. This article contains an exemplary enumeration of the tasks that fall within the exclusive competence of the municipal council.

When classifying them, the following tasks can be distinguished:

- intra-organisational,

- economic,

- local organisational,

- providing local legal acts,

- financial,

- administrative,

- granting honorary citizenship,

- control and supervisory ${ }^{29}$.

Intra-organisational tasks include the adoption of the municipal statute. This task is an exclusive competence of the municipal council, and the

27 J. P. Tarno, Samorzad terytorialny w Polsce, Warsaw 2004, p. 137-138.

28 M. Stych, Wybrane zagadnienia prawne statutu gminy jako aktu prawa miejscowego o charakterze ustrojowym, Ius et Administratio, Rzeszów 2014, p. 3.

29 B. Dolnicki, Ustawa o samorzadzie gminnym komentarz, Warsaw 2016, p. 93. 
statute itself is the most important act of an organisational nature. The determination of the scope of activities of the municipal auxiliary units can also be included in this category. This scope is to include the rules of transferring assets to them and the rules of transferring budget funds for the execution of tasks. Another example of this type of tasks is the determination of the mayor's remuneration and his/her line of action. The municipal council decides about the mayor's tasks and goals and approves reports on his/her activities. This also includes appointing and dismissing the municipal treasurer, who is the main accountant of the municipal budget. This is done at the request of the mayor and is personal in nature.

The adoption of a study on the conditions and directions of spatial development of the municipality, which is an obligatory act, constitutes an example of tasks of an economic nature. This task group also includes the adoption of local spatial development plans, once their compliance with the study's concepts has been recognised, and the adoption of economic programmes ${ }^{30}$, thanks to which the municipality can influence local entrepreneurship structures by stimulating and creating solutions conducive to attracting new investors and qualified employees ${ }^{31}$.

The group of local organisational tasks includes, among others, the adoption of resolutions on the municipality's coat of arms, names of streets and squares being public roads and names of internal roads, as well as resolutions on erecting monuments in the municipality. Financial tasks include such activities as adopting the municipality's budget and long-term financial forecasts. Moreover, this group of tasks includes adopting resolutions on taxes and fees within the limits set out in separate Acts of law (e.g. on real estate tax, tax on means of transport, agricultural and forestry tax, and local fees) ${ }^{32}$, as well as adopting resolutions on municipal property matters that exceed the scope of ordinary management, and determining the sum up to which the mayor may independently incur financial liabilities. The administrative tasks that fall within the competence of the municipal council are, for instance, adoption of resolutions on cooperation with other municipalities and allocation of appropriate assets for this purpose. Moreover, the council passes resolutions on matters of cooperation with local and regional communities of other countries and joining international associations of local and regional communities.

Within the framework of its control and supervisory powers, the council controls the activities of the mayor and municipal organisational and auxiliary units. This control takes place mainly through factual actions, such as examination of the report on the activities of the mayor or providing

30 B. Dolnicki, Samorząd terytorialny, Cracow 2006, p. 385-400.

31 A. Sztando, 'Struktura programów lokalnej polityki gospodarczej małych gmin', [in:] S. Dolata (ed.), Funkcjonowanie samorządu terytorialnego, Opole 1998, p. 377.

32 B. Dolnicki, Ustawa o samorządzie..., p. 404. 
opinions on the execution of the municipal budget ${ }^{33}$, performed through the Audit Committee.

\section{Municipal councillors}

The number of councillors who are members of the municipal council is specified in Article 17(1) of the Act on municipal government. According to it, the number of councillors sitting on the municipal council depends on the number of residents of a given municipality on the election day.

Table 1: Comparison of the number of councillors who are members of each municipal council in relation to the number of residents.

\begin{tabular}{|c|c|}
\hline $\begin{array}{c}\text { Number of councillors forming } \\
\text { the Municipal Council }\end{array}$ & $\begin{array}{c}\text { Number of the municipality's residents } \\
\text { in thousands }\end{array}$ \\
\hline 15 & up to 20,000 \\
\hline 21 & up to 50,000 \\
\hline 23 & up to 100,000 \\
\hline 25 & up to 200,000 \\
\hline
\end{tabular}

Source: The author's own elaboration based on the Act of 8 March 1990 on municipality government.

Additionally, in municipalities with more than 200,000 residents there are three more councillors, for each further 100,000 inhabitants. However, the legislator has defined the upper limit of the number of municipal authority representatives, indicating that there can be no more than 45 councillors. The statutory composition of the council is set proportionally to the number of the municipality's residents on the election day. It is closely related to the concept of a quorum. This is of great procedural importance as it guarantees the correctness of the resolutions adopted. They are passed by a simple majority of votes in the presence of at least half of the statutory composition of the council, in an open vote ${ }^{34}$. The results of roll-call votes are made available in the Public Information Bulletin and on the municipality's website. These lists may also be made public in a different way than is customarily adopted in the municipality. However, before proceeding to exercise their mandate, councillors are obliged to take an oath, the content of which is specified in the Act of 8 March 1990 on municipal government and the Code of Ethics of Councillors adopted by the municipal council. The councillor's mandate is a free one, which means that the councillor is not bound by instructions from his/her constituents ${ }^{35}$.

33 A. Szewc, T. Szewc, Uchwałodawcza działalność organów samorządu terytorialnego, Warsaw 1999, p. 16, 20.

34 M. Augustyniak, Samorząd..., p. 385.

35 Ibidem, p. 386. 
The rights and duties of a councillor are a consequence of the provisions of the Act of 8 March 1990 on municipal government and the municipal statute. The most important obligation resulting from the provisions of both legal acts is the obligation to participate in the work of the municipal council and its committees. Each case of attendance at council sessions or committee meetings must be confirmed by the councillor's signature on the attendance list. In case of his/her absence, the councillor should submit explanations to the chairman of the council or committee ${ }^{36}$.

\section{Conclusions}

As a result of the process of local-government and administrative reforms in Poland, an extensive local government structure has been created, covering all levels of the country's territorial division. The municipal council and other local-government bodies have not been granted the right to pass laws, nor do they have any competence of a relevant judicial authority. If they pass fundamental regulations (e.g. statutes, enforcement regulations, spatial development plans), this is done on the basis of explicit statutory authority. The executive power in Poland is created by the government and its subordinate administration, on the one hand, andby local authorities, including local government, on the other. The central and local government administration form a single public administration system in a complementary fashion. The overall reform of the Polish local government gives solid grounds for the conclusion that it remains in line with the European standards. It should be particularly emphasised that the model of local government adopted in the Polish constitutional system takes into account the application of the principle of subsidiarity as the main rule of the political system. The strategic goal of subsidiarity, apart from its political and legal dimensions, is to support the development of civil society institutions a society that is aware of its rights and obligations, that is able and willing to defend them, and that respects the rights and freedoms of others. On the other hand, the success and effectiveness of legal solutions inspired by this principle depends to a large extent on political culture, which consists of civic awareness. It manifests itself, among other things, in active involvement in the affairs of the territorial unit and its local community, electoral and institutional participation, willingness to compromise and social dialogue in which the interest of the community is overriding the interest of the individual.

36 Statut Gminy Tranów, Tarnów 2015, p. 4. 


\section{Bibliography}

Augustyniak M., Samorzad terytorialny, in: Prawo administracyjne, M. Zdyb, J. Stelmasiak (eds.), Warsaw 2016.

Bandarzewski K., Chmielnicki P., Kisiel W., Prawo samorządu terytorialnego w Polsce, Warsaw 2006.

Brol R., Kryteria delimitacji powiatów, in: Gospodarka lokalna i regionalna w teorii i praktyce, R. Brol (ed.), Wrocław 2004.

Chmielnicki B., Komentarz do ustawy o samorządzie województwa, Warsaw 2005.

Dolewka Z., System kontroli i nadzoru w samorządzie terytorialnym, Wrocław 2013.

Dolnicki B., Samorzad terytorialny, Cracow 2006.

Dolnicki B., Ustawa o samorzadzie gminnym komentarz, Warsaw 2016.

Gołębiowska A., Istota samorzadu terytorialnego w świetle postanowień Konstytucji Rzeczypospolitej Polskiej z dnia 2 kwietnia 1997 r., Warsaw 2015.

Gołębiowska A., Local Government in the 1997 Constitution of Republic of Poland, Warsaw 2015.

Gołębiowska A., Zientarski P., Funkcjonowanie samorządu terytorialnego - uwarunkowania prawne i społeczne, Warsaw 2016.

Gołębiowska A., Zientarski P., Stępień E., Konstytucja Rzeczypospolitej Polskiej a samorząd terytorialny, in: A. Gołębiowska, P. Zientarski (eds.), Funkcjonowanie samorzadu terytorialnego - uwarunkowania prawne i społeczne, Warsaw 2016.

Harańczyk A., Samorząd terytorialny - organizacja i gospodarka, Cracow 2010.

Kusiak-Winter R., Wspótpraca ze społecznościami lokalnymi i regionalnymi innych państw jako zadanie jednostek samorządu terytorialnego w Polsce, Wrocław 2015.

Leoński Z., Samorząd terytorialny w RP, Warsaw 1998.

Leoński Z., Zarys prawa administracyjnego, Warsaw 2004.

Stych M., Wybrane zagadnienia prawne statutu gminy jako aktu prawa miejscowego o charakterze ustrojowym, Ius et Administratio, Rzeszów 2014.

Suchodolski B., Zarys historii administracji samorządowej w Polsce, Siedlce 2013.

Szewc A., Szewc T., Uchwałodawcza działalność organów samorządu terytorialnego, Warsaw 1999.

Tarno J. P., Samorzad terytorialny w Polsce, Warsaw 2004.

Tecław D., Ewolucja samorzadu terytorialnego w Polsce w latach 1989-1998, Poznań 2015.

Zięba-Załucka H., Samorząd terytorialny Rzeczypospolitej Polskiej po reformie ustrojowej, Rzeszów 1999.

Legal acts

European Charter of Local Self-Government of 15 October 1985. Journal of Laws 1994 No. 124, item 607.

Constitution of the People's Republic of Poland passed by the Legislative Sejm on 22 July 1952. Journal of Laws 1952 No. 33, item 232.

Constitution of the Republic of Poland of 17 March 1921. Journal of Laws 1921 No. 44, item 267. 
Constitution of the Republic of Poland of 2 April 1997. Journal of Laws 1997 No. 78, item 483.

Constitution of 3 May 1791 (Governmental Act of 3 May 1791).

Constitutional Act of 23 April 1935. Journal of Laws 1935 No. 30, item 227.

Act of 23 March 1933 on partial change of the local government system. Journal of Laws 1933 No. 35, item 294.

Act of 24 July 1998 on the introduction of a basic three-tier territorial division of the State. Journal of Laws 1998 No. 96, item 603.

Act of 5 June 1998 on district government. Journal of Laws 1998 No. 91, item 578.

Act of 5 June 1998 on provincial government. Journal of Laws 1998 No. 91, item 576.

Act of 8 March 1990 on municipal government. Journal of Laws 1990 No. 16, item 95.

Act of 27 March 2003 on spatial planning and development. Journal of Laws 2003 No. 80, item 717.

Regulation of the Council of Ministers of 7 August 1998 on the establishment of districts. Journal of Laws 1998 No. 103, item 652.

Abstract

The article presents selected aspects being a consequence of the evolution of local government in Poland. The main attention is focused on the presentation of the structure and competences of the municipal council, in the context of systemic changes of local government. The article is of a review nature character and its aim is to diagnose organisational solutions concerning the municipal council in Poland. The main premise of the article implies that the process of evaluation of the structure and functioning of the municipal council is conditioned by involvement of the local residents who experience its influence on their daily lives, including meeting their needs. Decentralisation and participation of local community members in local government structures such as the municipal council or other bodies are key issues in civil society development. The process of local government evolution has not been completed and localgovernment organisation and functionality does not deviate from European standards.

Keywords: municipality, municipal council, local government, participation, administrative division, reform 